\title{
Statistical Process Control Methods For Determining Defects of Denim Washing Process: A Textile Case From Turkey
}

\author{
Serhat Ata ${ }^{1}$, Mehmet Selami Yildız ${ }^{2}$ İsmail Durak ${ }^{3}$ \\ ${ }^{1}$ Research Assistant at Düzce University. \\ ${ }^{2}$ Professor Doctor at Düzce University. \\ ${ }^{3}$ Assistant Professor at Düzce University
}

Corresponding Author: Serhat Ata, serhatata@duzce.edu.tr

\begin{abstract}
The denim garments, which are made with many different sewing patterns, are given the final appearance by applying industrial washing processes and these are turned into high value-added fashion products. In this study, denim fabric control performed in a textile company, washing department after weaving for one month was investigated and as a result, washing defects are examined by using statistical methods. Pareto analysis, cause and effect diagram, and P control graphs, which are statistical process control methods, were used to classify the defects seen as a result of quality control. In Pareto analysis, chemical repair (20, $52 \%)$, blue floor (19, $86 \%$ ), chemical intensive $(19,56 \%)$, light floor $(10,71 \%)$, deep floor $(7,95 \%)$ are in first five places among 53 defects and account for 78, $6 \%$ of total number of defects. Of the 53 defects encountered during the washing process, it is found that only five of these defects could be prevented during the washing process, thus reducing the total waste by about $80 \%$. In cause and effect diagram, washing defects are divided into categories as chemical, foreground, intensity, repair, tinctorial and processual and subdimensions as causes are determined. In the Laney P control chart, all processes are determined under control.
\end{abstract}

\section{ARTICLE HISTORY}

Received: 27.02.2020

Accepted: 10.07.2020

\section{KEYWORDS}

Denim Washing Defects in Process, Statistical Process Control, Pareto Chart, P-Chart, Cause and Effect Diagram

\section{INTRODUCTION}

The textile sector is one of the traditional industries, providing employment opportunities and in terms of the value-added creating during the production process, from past to present is a sector that affects the economy of Turkey significantly. As the most important part of the textile sector, denim garments, and clothing made of this fabric, which is one of the oldest fabric types in the world, can always remain young, but as a result of the intensive product development efforts that have been going on for years, it is a family-wearable type that can be worn in the wardrobe of people of all ages and has become textile and apparel products which are perceived as high fashion clothes by some circles [1]. Denim garments are produced from denim fabrics, which is one of the oldest fabric types in the world and can always remain young as a result of years of intensive product development activities. In readymade clothing, especially in types of denim, one color can be used, and contrasting colors, shades of the same color, and neighboring colors can be preferred [2]. The denim products which can be worn after the garments are delivered either to the customer in a dry state (without washing) or according to the fashion demands, or subjected to various washing processes that were applied in the 1970 s and which create a distinct fashion today. Today, the share of dry denim products that meet the customer without washing does not exceed 3\% of total denim product production. For this reason, denim washing has a very important place today. When the 2018 January and December period, the product groups based on Turkey's

To cite this article: Ata S, Yıldız MS, Durak İ. 2020. Statistical process control methods for determınıng defects of denım washıng process: a textıle case from Turkey. Tekstil ve Konfeksiyon, 30(3), 208-219. 
special yarn and fabric exports is observed that the most important product group in denim fabric exports valued at 341 million dollars, and this value constitutes $51.2 \%$ of the total special yarn and fabric exports [3]. One of the important operations for denim fabric products is washing operation. Washing is seen as the final process in denim production and is the base of denim finishing [4]. The washing process is the process of washing the sewn denim garment in special washing machines according to certain prescriptions and techniques, removing the sizing on it, and giving it different colors and touches. Denim washing technology aims to create new color tones and effects on consumer demands and the effect of fashion. The main feature of denim is that it is dyed with indigo dye which is discolored as it is washed [5]. Washing of denim products can be

carried out either as a garment or as a fabric. The purpose of the washing process in the form of fabric before the garment is to lighten the denim fabrics, to provide a tensile strength in the fabric, and to remove the hard attitude in the raw fabric. Washing in the form of garments takes place in the form of washing of the finished textile products in a rotary drum garment machine according to various principles [6]. The purpose of this study and the most important difference that emphasizes the study is to determine what are the most common defects during and after denim washing with statistical methods and to test whether these defects are controlled in terms of quality. In the following sections of the study, denim washing process will be evaluated in a general framework, the findings and results obtained by statistical process control methods will be discussed and some suggestions will be made.

\section{OVERVIEW OF DENIM WASHING PROCESS}

Denim washing is a process with too much input. Therefore, many parameters influence color. These parameters can be extended from the property of the fiber and yarn to the product stage. In conventional washing, it is aimed that the color difference between the boilers is tolerable in the washing of the finished products with the same prescription. The results obtained in the intermediatewash controls and post-wash final controls are compared with the customer request [7]. The washing steps of denim can be categorized as follows [8]:

Desizing refers to a leaving starch denim garments is to provide amylase enzyme. This material can break down long molecular (water-insoluble) starch chains into shorter (water-soluble) molecules that can be washed away more quickly. Rinsing has only one aim for wash and it is to make the garment wearable. During the construction of denim fabric, starch is applied to strengthen the warp. This makes the fabric stiff and harsh to the skin. In rinse wash the garment is desized and some softening agent is applied to improve the hand feel of the garment. Denim abrasion with enzymes provides a high color-contrast finish, high color pull and a low degree of back-staining, reduces equipment wear and tear compared to washing with pumice stones and It is also available for temperatures as low as $30^{\circ} \mathrm{C}$ and combined de-sizing and abrasion (single process step). Softening is the process that gives a soft touch to denim products, washing machines are softened. In industrial denim washing 3 types of softeners are used: Cationic softeners: All soft products except white products have a soft touch. They provide white and light-colored products that cause yellowing. Non-ionic softeners: They are used to soften white and light-colored products. Their effects are less than cationic softeners because they do not infiltrate into the product they remain on the surface. Silicones: They give the product softness as well as lubricity [1]. The drying time affects the hand feel. After washing, denim garments are hydroextracted to remove $80 \%$ of water content before drying. During drying, the number of denim garments in the dryer should not be too great. Too many denim garments in the dryer need a longer drying time which increases the contact between the garments leading to back staining. The denim garments are dried and packed for delivery [6]. Industrial washing processes of denim products are divided into two groups as dry processes and wet processes. Dry operations are sanding, whisker effect, damage, swift, and laser operations. Wet processes are resin spray, permanganate spray, pigment spray, desizing, stone washing, crinkle, enzyme washing, bleaching, tint, softening, and other special processes. The purpose of the sanding process is to give locally worn effect to certain areas of the denim garment. Standard metal sanders with 180 to 600 tines per square inch are used for this process. In the process, the operator abrades the indigo dye that covers only the outer part of the warp thread by applying the suitably sanded product to the desired color removal section of the product. The product to be sanded is dressed on horizontal mannequins (chamber) inflated by air pressure. Abrasion is applied with sandpaper according to the target product. However, because they cause the disease slikosis among employees, Republic of Turkey Ministry of Health issued a circular in 2009, and in all kinds of denim and fabric applied to the spraying process, the use of sand, silica powder or any substance containing silica crystals had been banned [9]. The purpose of the whisker process is to obtain worn and worn-looking lines resulting from creases and wrinkles in the garment used for a long time [10]. The purpose of the destruction (damage) process is based on the principle of shredding warp yarns in certain areas of denim products to reveal only weft yarns and simulate the longterm wear of the products. Therefore, this effect is called the destruction (damage). Laser operations are the process of giving effect by burning the denim fabric from the areas where the laser touches on the laser machine. Denim fabric can be made in the most open laser process or as a finished product. Swift technique is made in the raw state of denim 
products. Plastic blades are punched to the desired area with the machine designed for this application. The purpose of the application is to ensure that the stapled areas do not receive the washing effect applied during the washing. When these blades are removed after washing, the desired effect is obtained on the product [11]. Resin spray is generally applied as the first process in wet processes. It is made by a spray gun or by dipping method. It is used to keep the color dark in case of very dark washing. For example, when a process consisting of only 10 minutes of prewash is made to the resinous fabric, the color remains darker than the non-resinous one. It is made for better results in sanding areas. The dipping resin is mostly used for wrinkles or hard touches.

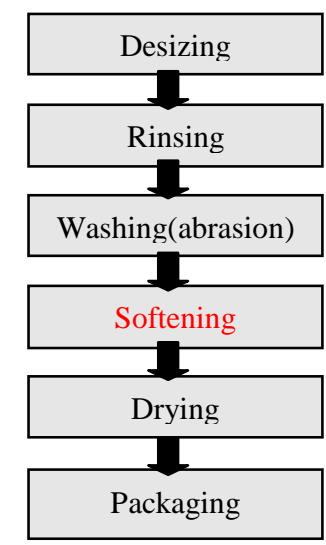

Figure 1. Denim Washing Process [8]

The effect of the resin leads to contrast images, especially in crosswise stitches, pocket stitches, and waist. Resinated clothing has a more fragile structure. Bleaching with permanganate is mainly used in local processes (such as spraying with guns) and in bleaching fabrics containing elastane and a mixture of fibers damaged under the influence of temperature and hypochlorite, and after bleaching, neutralization with peroxide or bisulfite should be performed. The large size of the permanganate molecules makes the color bleaching process more controlled and slower. However, in large stitched regions, the large molecule is disadvantageous and in these regions, the color remains dark [12]. Pigment sprays are applied only to color the outer parts of the products. In the stone washing process, freshly painted jeans are loaded into the large washing machine and rotated with a soft hand and a pumice stone or volcanic rock to achieve the desired appearance. Composition types, hardness, size shape, and porosity make this stone multifunctional. The process is very expensive and requires high capital investment. Pumice stone abrades the denim surface, such as sandpaper, creating a faded or worn appearance and removing some paint particles from the surfaces of the yarn. Crinkle is called the application of the desired effect on the product to the desired region by fixing the crushing effect with special chemicals in the oven at high temperatures. Wrinkle crinkle effect is obtained in the product after application. This effect will not disappear even if the product is washed again. An enzyme is a kind of protein, has been used in the textile industry in recent years, and has come to the forefront in the washing sector because of its ability to break down starch and cellulose. The ground color of the products is tried to be captured by enzymes used according to different species and temperatures. Bleaching is the process of fading the color of denim products. It is effective in cotton products. This is a kind of reduction reaction. This is done using potassium permanganate or sodium hypochlorite. After capillary pumice overflow impregnation of reducing chemicals, only stone and product are treated in a washing machine. Tint (Dirty) washing is a type of washing that is done by applying special dyes of different colors and features in hot water. It is applied to give the product a dirty or antique appearance [13]. Finally, in the softening process, the final image of the fabric is captured. Most often cationic softeners are applied to the fabric in a weak acid environment. These ammonium-based substances contain chemically oil-containing groups, depending on the nature of these groups, called silicon or normal emollients. While only a soft touch can be obtained with normal softeners, a silky touch is obtained with silicon softeners [14]. In the manufacturing sector, there may be defects in every stage of production and in the textile sector; the formation of a defect in the denim washing processes is inevitable.

In denim washing and use, chemical defects such as back dyeing yellowing, inability to achieve regional color and nuance shift in the product, inability to achieve color fastening due to bleaching, color changes due to softener and resin, green in nuance, lack of gray or blue tone, inadequate blue, and white contrast, excessive bleaching may occur. Further, mechanical defects such as fractures, tears, wear caused by garments, dry process based on defects, accessory welded defects may occur. Further, heatinduced defects such as excessive drying and combustion may emerge [1].

\subsection{Literature Review}

According to literature review, in one [15] study related to the influence of denim washing, as industrial properties and washing on fabric properties, the structural features, shrinkage, air permeability, bending rigidity, extensibility, breaking force and elongation, shear rigidity has been determined. Additionally, [16] in other study researchers define mechanical properties of denim garments after enzymatic bio-machine washing processes and it is found that treatment of denim with different enzymes and stones may cause different effects. In the research about the effect of different washing processes on various performance and surface properties of denim fabrics were examined and for this purpose, 3 different types of fabrics (1/1 plain, 2/2 twill, and $3 / 1$ twill constructions) were produced from $100 \%$ cotton yarn, and 4 different types of washing processes (rinse, enzyme, stone, and stone+bleach) were applied [17]. The effect of woven structure and washing processes on denim fabrics performance properties like dimensional stability, breaking strength, tearing strength, 
bending rigidity, surface views examination, and colorimetric valuation were investigated statistically. At the end of the washing process, when the surface appearance and color values of samples combined with the mechanical effect, chemical applications (stone+bleach) of fabric made significant changes on denim color values. In real concept analyzing quality control in garment company and aiming to determine the application of quality control by using statistical tools which can be convenient to control the level of disability products in the company, know the type of disability dominant, and provide solutions for problems facing by the company in other studies[18]. The result of their Pareto analysis diagram showed that major types of rejected products were the defected clothes (31.53\%), broken $(28.40 \%)$, and disability accessories (20.98\%), nevertheless, the dominant type of defect was the defect in fabric. Based on the analysis of the control $u$ map, it

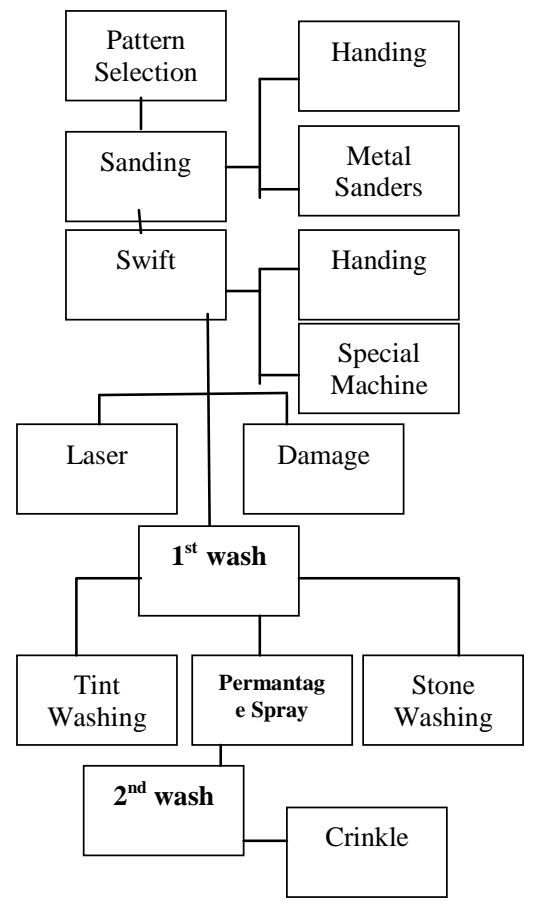

Figure 2. An alternative Flowchart for denim washing process

showed that there were still samples outside the control limits. From the analysis of the causal diagram, it can be concluded that disability products were derived from working systems, human/labor, materials/raw materials, and machinery. To augment, the perceptible raw materials become the main factor causing the fabric defect in the study. To determine the quality control on finished jeans and in the quality control segment, one study referred to the possible defects like strength loss, shading, stains, yellowing, and seaming that influence marketability or serviceability of denim garments are discussed and the possible solutions are suggested. The results obtained after dry and wet processes are a combined effect of mechanical abrasion, color dissolution, and destructive processes [19]. To enhance observations of the effects of Pareto analysis and Cause and Effect diagram, it is mentioned in the garment sector in Bangladesh that minimizing defects percentage and applied these methods. It is found that 6 top defect positions (Uncut Thread, 23.72\%; Spot, 20.70\%; Waist Belt,11.67\%; Bottom Hem, 10.04\%; Side Seam, $6.30 \%$; Waist Belt Top Stitch, 6.14\%) are identified where $78.56 \%$ defects occur. On those top positions, further Pareto Analysis is performed to identify the top defect types. It is resulted in a total of 115 regarding areas where $71.40 \%$ defects arise, which should be the foremost concerning areas to lessen defect percentage [20]. In other study, investigation is about the chemical oxygen demand (COD) and color removal efficiency and specific energy consumption during batch electrochemical treatment of synthetic textile wastewater and containing yellow-brown acrylic dye and found that COD (0.8815), color (0.9494), and specific energy consumption $(0.9331,0.8805)$ by Pareto chart. It shows that chemical oxygen demand brought the wastewater problem into the forefront [21].

\section{MATERIALS AND METHODS}

The statistical process control that forms the core of the method of this study is a quality control method used to continuously control a process and to control the variability in the process. Statistical process control is the use of various statistical techniques to ensure a product that is produced in the most economical and most useful way, to target its defective variability produced at this point [22]. According to Professor K. Ishikawa, 95\% of the problems encountered in the industry can be solved with seven basic techniques. These techniques are flow diagram, check sheets, Pareto analysis, cause and effect diagram, histogram, scatter diagram, and control cards [23].

In this study, the defects encountered in the washing process in a denim factory are identified and designated, and the most common defects are examined using statistical process control methods, Pareto analysis, cause and effect diagram, and $P$ control graph. During the washing process, it is not possible to prevent all defects detected over quality control. With the Pareto analysis technique, many defect types are listed according to importance. Thus, the most important washing process defects are identified. The results of quality control are examined with $P$ control charts. In this way, it is aimed to present the necessary regulations to control the continuity of the quality level, to control the process, and to achieve the targeted product quality.

\subsection{An Overview of Pareto Chart, Cause-and-Effect Diagrams and $\boldsymbol{P}$ Control Chart}

Pareto analysis is called as $\mathrm{ABC}$ analysis or sometimes (20/80) rule. According to this principle, the majority of nonconformities are based on many reasons, and the identification of these causes plays a key role in solving the problems. In economics, $80 \%$ of the outputs, $20 \%$ of the inputs; $80 \%$ of the results will arise from the basis of $20 \%$ 
of the reasons and the $80 / 20$ rule, which is expressed as Pareto, is based on the idea that $80 \%$ of problems can be solved by eliminating the causes accounting $20 \%$ of all problems [24].

The reason for using the Pareto analysis technique in this study is that there are many flaws encountered in the washing process, but not all of them affect the whole process. If the main defects affecting the whole process are eliminated, the process can be continued even if there are other defects. After determining the problem to be investigated in the drawing of the Pareto diagram, the information collected with the appropriate data schedule is used. The collected data is sorted in descending order according to the unit quantities. The others are placed in the last row, regardless of size. The cause-effect diagram is prepared to reveal the relationship between a particular result and possible causes, and thus the causes of defects, and is drawn to show the connections of factors that affect a process. A detailed diagram is in the form of fishbone, developed by the Japanese Ishikawa, often referred to as the Ishikawa Diagram. When the diagram is drawn, the problem is identified, and possible causes are written in the main categories [25]. When the main reason is considered as washing process errors, all the reasons causing will be identified and categorized in the diagram. To change from a monitoring-based system to a prevention-based system, it is necessary to see and control the variation in process output over time. Thanks to the $p$ control graphs showing the changes over time, the measured values obtained from the samples taken at certain and equal time intervals from production; It is recognized that the changes in the process are caused by natural or unnatural reasons [26]. Sampling for $P$ control chart includes the yes / no decision. The process output may be defective or not defective. Statistical distribution is based upon the binomial distribution. The number of products controlled in the enterprise examined varies. In enterprises where $100 \%$ inspection is performed or the number of products controlled in proportion to the production amount varies, the control chart will have variable sample sizes. The approach that can be followed in such cases is to set separate control limits for each sample. In case the sample size is $\mathrm{n}_{i}$ and the standards are determined, the midline, upper, and lower control limits are calculated by the following formula [27]:

\subsection{Methodology}

The study was conducted in Turkey on a production company engaged in the production of denim in Düzce. Within the scope of the research, Pareto diagram, $P$ control chart, and cause and effect diagrams were formed over the defects that occurred during the washing process.

\subsection{Data Collection and Analysis}

Data were obtained through interviews in a production company, by a production manager and director of the washing department. The data in the department only include working days of November 2019 and weekends (Saturday and Sunday or Sunday only) are not included. So the data consist of 25 days. There are two shifts in the shape of day and night in washing section as the same in all production process. In data set obtained, 53 defects are classified as chemical repair, blue floor, rinsing, green floor, press, retouch, chemical intensive, light floor, deep floor, neutral repair, hard touching, panel difference, flaw, local repair, stained works, lycra eccentric, chemical above green, coating repair, branch flaw, yellow floor, downy works, rope cut, blue above whisker, being blown out, chemical above yellow, pigment repair, red floor, grey floor, moiré works, random repair, straight floor, stripe defect, resin intensive, resin broken, over effect, resin stain, fray repair, coating line, washing repair, orange floor, chemical segregation, fabric difference, whisker repair, fray off, and fabric tear. Business employees have some ideas about the potential causes of defects. Although several attempts have been made previously, no registered studies have been found. In previous studies available in the enterprise, no research on the prevention of washing defects was found. This situation makes this study more important.

\section{FINDINGS IN PROCESS AND STATISTICAL EVALUATION}

Table 1 was prepared with the purpose of checking the distribution of defects. Total defects are found and reported as 176240 washing process defects as a result of the control of 759259 denim in 25 days. In the total part, the number of each error recorded in the control cards in 759259 units is given. When controlling the column of total numbers, it is ranged as first chemical repair (36382 defects) and last and the lowest fabric tear ( 9 defects).

$$
U C L=\bar{p}+3 \sqrt{\left(\frac{\bar{p}(1-\bar{p})}{n_{i}}\right)} \quad C L=\bar{p}=\frac{\sum p_{i}}{\Sigma n_{\bar{i}}} \quad L C L=\bar{p}-3 \sqrt{\left(\frac{p(1-\bar{p})}{n_{\bar{i}}}\right)}
$$


Table 1. Defects Tracking Report

\begin{tabular}{|c|c|c|c|c|c|c|c|c|}
\hline Defects/Days & 1 & 2 & 4 & .. & 28 & 29 & 30 & Total \\
\hline Chemical Repair & 1460 & 546 & 1992 & .. & 2279 & 2437 & 1275 & 36382 \\
\hline Blue Floor & 1565 & 427 & 1422 & .. & 2568 & 2028 & 1281 & 35216 \\
\hline Chemical Intensive & 1123 & 1592 & 1239 & .. & 1152 & 662 & 534 & 34674 \\
\hline Light Floor & 289 & 588 & 193 & .. & 1202 & 391 & 574 & 18984 \\
\hline Deep Floor & 1130 & 920 & 1036 & .. & 242 & 636 & 257 & 14099 \\
\hline Neutral Repair & 6 & 0 & 417 & .. & 0 & 0 & 207 & 5526 \\
\hline Chm. Above Yellow & 0 & 117 & 0 & .. & 245 & 164 & 240 & 5197 \\
\hline Pigment Repair & 0 & 275 & 48 & .. & 0 & 87 & 100 & 4720 \\
\hline Retouch & 500 & 13 & 0 & .. & 192 & 138 & 50 & 3570 \\
\hline Rinsing & 118 & 856 & 110 & .. & 102 & 0 & 121 & 3324 \\
\hline Yellow Floor & 0 & 30 & 130 & .. & 144 & 12 & 182 & 1715 \\
\hline Green Floor & 20 & 453 & 0 & .. & 14 & 200 & 0 & 1713 \\
\hline Press & 200 & 0 & 65 & .. & 192 & 0 & 0 & 1322 \\
\hline Local Repair & 0 & 0 & 380 & .. & 0 & 28 & 50 & 1316 \\
\hline Resin Broken & 0 & 0 & 0 & .. & 0 & 0 & 0 & 1134 \\
\hline Panel Differ. & 44 & 72 & 0 & .. & 94 & 10 & 0 & 964 \\
\hline Stained Works & 0 & 0 & 0 & .. & 0 & 0 & 0 & 814 \\
\hline Red Floor & 0 & 50 & 0 & .. & 0 & 0 & 0 & 583 \\
\hline Straight Floor & 0 & 0 & 0 & .. & 224 & 0 & 0 & 579 \\
\hline Lycra Eccentric & 0 & 0 & 0 & .. & 0 & 500 & 66 & 566 \\
\hline Grey Floor & 0 & 50 & 27 & .. & 0 & 0 & 0 & 552 \\
\hline Chemical Burnt & 0 & 0 & 0 & .. & 236 & 0 & 0 & 505 \\
\hline Random Intensive & 0 & 0 & 0 & .. & 0 & 0 & 0 & 483 \\
\hline Stripe Defect & 0 & 0 & 293 & .. & 0 & 0 & 0 & 403 \\
\hline Downy Works & 0 & 0 & 0 & .. & 101 & 0 & 0 & 340 \\
\hline Random Repair & 0 & 0 & 0 & .. & 0 & 0 & 0 & 260 \\
\hline Random Stain & 0 & 0 & 0 & .. & 0 & 0 & 0 & 249 \\
\hline Washing Repair & 0 & 0 & 0 & .. & 0 & 0 & 0 & 248 \\
\hline Resin Stain & 0 & 0 & 0 & .. & 0 & 0 & 0 & 219 \\
\hline Moiré Works & 0 & 67 & 0 & .. & 0 & 0 & 0 & 134 \\
\hline Fray Repair & 0 & 0 & 0 & .. & 11 & 20 & 0 & 131 \\
\hline Coating Line & 0 & 0 & 0 & .. & 0 & 0 & 0 & 122 \\
\hline Orange Floor & 0 & 0 & 0 & .. & 0 & 0 & 0 & 121 \\
\hline Mesh Intensive & 0 & 0 & 0 & .. & 0 & 0 & 0 & 100 \\
\hline Whisper Repair & 0 & 0 & 0 & .. & 0 & 20 & 71 & 91 \\
\hline Blue Whisker & 0 & 89 & 0 & .. & 0 & 0 & 0 & 89 \\
\hline Flaw & 48 & 0 & 0 & .. & 0 & & 0 & 86 \\
\hline Dye Slump & 0 & 0 & 0 & .. & 0 & 0 & 0 & 85 \\
\hline Chemical Segregat. & 0 & 0 & 0 & .. & 79 & 0 & 0 & 79 \\
\hline Chemical Light & 0 & 0 & 0 & .. & 0 & 0 & 0 & 74 \\
\hline Fray Off & 0 & 0 & 0 & .. & 0 & 0 & 74 & 74 \\
\hline Be. Blown Out & 0 & 57 & 0 & .. & 0 & 0 & 0 & 57 \\
\hline Over Effect & 0 & 0 & 0 & .. & 0 & 0 & 0 & 53 \\
\hline Coating Repair & 0 & 48 & 0 & .. & 0 & 0 & 0 & 48 \\
\hline Fabric Dif. & 0 & 0 & 0 & .. & 43 & 0 & 0 & 43 \\
\hline Local Blue & 0 & 0 & 0 & .. & 0 & 0 & 0 & 40 \\
\hline Resin Intensive & 0 & 0 & 18 & .. & 0 & 0 & 0 & 37 \\
\hline Hard Touching & 34 & 0 & 0 & .. & 0 & 0 & 0 & 34 \\
\hline Chemical Green & 0 & 25 & 0 & .. & 0 & 0 & 0 & 25 \\
\hline Branch Flaw & 0 & 23 & 0 & .. & 0 & 0 & 0 & 23 \\
\hline Rope Cut & 0 & 0 & 0 & .. & 19 & 0 & 0 & 19 \\
\hline Leg Conversion & 0 & 0 & 0 & .. & 0 & 0 & 0 & 11 \\
\hline Fabric Tear & 0 & 0 & 0 & .. & 0 & 0 & 9 & 9 \\
\hline Denim Cont. & 34791 & 29293 & 39561 & .. & 32374 & 28659 & 15426 & 759259 \\
\hline Total Defects & 6437 & 6298 & 7370 & .. & 9139 & 7333 & 5088 & 176240 \\
\hline
\end{tabular}

With the intention of preliminary preparation for Pareto analysis, Table 2 was comprised by calculating the defect percentages and cumulative percentages by ordering the total number of washing process defects in the defect tracking report from large to small. According to table of number of defects observed during washing process 
respectively chemical repair $(20,52 \%)$, blue floor $(19,86$ $\%)$, chemical intensive $(19,56 \%)$, light floor $(10,71 \%)$, and deep floor $(7,95 \%)$ have great impact on increasing $\%$ of defects when checking cumulative percentage.

Among the 53 washing defects examined, the Pareto diagram in Figure 1 was created by using the data in Table 2 to determine the defects that comprise $80 \%$ of the total defects. In Pareto analysis formed, chemical repair $(20,52$ $\%)$, blue floor $(19,86 \%)$, chemical intensive $(19,56 \%)$, light floor $(10,71 \%)$, deep floor $(7,95 \%)$ are in first five places among 53 defects and account for $78,6 \%$ of the total number of defects. (See Table 2, See Figure 3).

In this study, the reason for using Pareto diagram in this study shown in Figure 3 is to is to guide the quality control staff in determining the types of defects, to ensure that their efforts are concentrated in the most productive fields and that the necessary measures are taken by making accurate decisions. Of the 53 defects encountered during the washing process, it was found that only five of these defects could be prevented during the washing process, thus reducing the total waste by about $80 \%$.

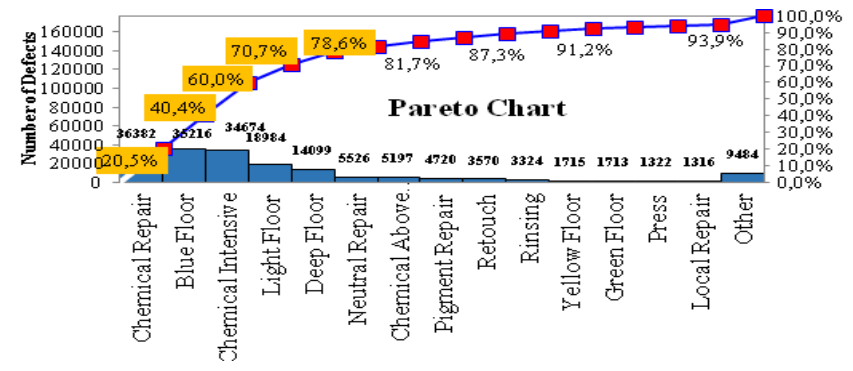

Figure 3: Pareto Chart for Denim Washing Defects

Table 2: Number of Defects Observed During Washing Process

\begin{tabular}{|c|c|c|c|c|c|c|c|}
\hline Defect Name & $\begin{array}{l}\text { Number } \\
\text { of } \\
\text { Defects }\end{array}$ & $\%$ of Defect & Cum \% & Defect Name & $\begin{array}{l}\text { Number } \\
\text { of Defects }\end{array}$ & $\%$ of Defect & Cum \% \\
\hline $\begin{array}{l}\text { 1.Chemical } \\
\text { Repair }\end{array}$ & 36382 & 20,52 & 20,52 & 28.Washing Repair & 248 & 0,14 & 99,06 \\
\hline Blue Floor & 35216 & 19,86 & 40,38 & Resin Stain & 219 & 0,12 & 99,18 \\
\hline $\begin{array}{l}\text { Chemical } \\
\text { Intensive }\end{array}$ & 34674 & 19,56 & 59,94 & Moiré Works & 134 & 0,07 & 99,25 \\
\hline Light Floor & 18984 & 10,71 & 70,65 & Fray Repair & 131 & 0,07 & 99,32 \\
\hline Deep Floor & 14099 & 7,95 & 78,6 & Coating Line & 122 & 0,06 & 99,38 \\
\hline Neutral Repair & 5526 & 3,11 & 81,71 & Orange Floor & 121 & 0,06 & 99,44 \\
\hline $\begin{array}{l}\text { Chemical Above } \\
\text { Yellow }\end{array}$ & 5197 & 2,93 & 84,64 & Mesh Intensive & 100 & 0,05 & 99,49 \\
\hline Pigment Repair & 4720 & 2,66 & 87,3 & Whisper Repair & 91 & 0,05 & 99,54 \\
\hline Retouch & 3570 & 2,01 & 89,31 & $\begin{array}{l}\text { Blue Above } \\
\text { Whisker }\end{array}$ & 89 & 0,05 & 99,59 \\
\hline 10.Rinsing & 3324 & 1,82 & 91,13 & Flaw & 86 & 0,04 & 99,63 \\
\hline Yellow Floor & 1715 & 0,96 & 92,09 & Dye Slump & 85 & 0,04 & 99,67 \\
\hline Green Floor & 1713 & 0,96 & 93,05 & $\begin{array}{l}\text { Chemical } \\
\text { Segregation }\end{array}$ & 79 & 0,04 & 99,71 \\
\hline Press & 1322 & 0,84 & 93,89 & 40.Chemical Light & 74 & 0,04 & 99,75 \\
\hline Local Repair & 1316 & 0,83 & 94,72 & Fray Off & 74 & 0,04 & 99,79 \\
\hline Resin Broken & 1134 & 0,71 & 95,43 & Being Blown Out & 57 & 0,03 & 99,82 \\
\hline Panel Difference & 964 & 0,54 & 95,97 & Over Effect & 53 & 0,03 & 99,85 \\
\hline Stained Works & 814 & 0,45 & 96,42 & Coating Repair & 48 & 0,03 & 99,88 \\
\hline Red Floor & 583 & 0,32 & 96,74 & Fabric Difference & 43 & 0,02 & 99,90 \\
\hline Straight Floor & 579 & 0,32 & 97,06 & Local Blue & 40 & 0,02 & 99,92 \\
\hline $\begin{array}{l}\text { 20.Lycra } \\
\text { Eccentric }\end{array}$ & 566 & 0,31 & 97,37 & Resin Intensive & 37 & 0,02 & 99,94 \\
\hline Grey Floor & 552 & 0,31 & 97,68 & Hard Touching & 34 & 0,02 & 99,96 \\
\hline Chemical Burnt & 505 & 0,28 & 97,96 & $\begin{array}{l}\text { Chemical Above } \\
\text { Green }\end{array}$ & 25 & 0,01 & 99,97 \\
\hline Random Intensive & 483 & 0,27 & 98,23 & Branch Flaw & 23 & 0,01 & 99,98 \\
\hline Stripe Defect & 403 & 0,22 & 98,41 & Rope Cut & 19 & 0,01 & 99,99 \\
\hline Downy Works & 340 & 0,19 & 98,64 & Leg Conversion & 11 & 0,005 & 99,99 \\
\hline Random Repair & 260 & 0,14 & 98,78 & 53.Fabric Tear & 9 & 0,005 & 100,0 \\
\hline Random Stain & 249 & 0,14 & 98,92 & & & & \\
\hline
\end{tabular}


Chemical repair, which constitutes $20.52 \%$ of the total defect in the washing process, includes parts of the denim in the washing process that can be repaired after exposure to the chemical. $19,56 \%$ of the total defects are the chemical intensive, that denim is included non-repairable products as a result of exposure to excess chemical. The first of the chemicals used in the washing process; desizing enzymes is the process, that make the starch contained in the sizing water-soluble, prewash process, and the nonfoaming-hard water having a $\mathrm{pH}$ of 6-7. If the enzyme does not remove the dye and scalp homogeneously, a fracture will occur in these areas [28]. This causes irreparable damage. The sizing material is usually based on starch or modified starch, although some wetting chemicals and emollients are also present in the sizing recipe. These chemicals should be removed from the fabric as it reduces the effects of chemicals to be used in washing operations to be made on denim garments. Unless a proper desizing is done, the possibility of abraj formation in the fabric is quite high. A desizing process that cannot be done sufficiently will cause unnecessary consumption as it will reduce the effect of chemicals to be given to the fabric in the next stages.

Other chemical processes that increase the light fastness of denim fabric optic whiteners, disintegrated dyes or indigos by dispersing the fabric to reduce the permeability of the fabric, washing the enzyme to keep the dye to help enzyme to reduce the effect of sunlight, and shine under the brightening phosphorus brighteners used to obtain the appearance of bright jeans, cationic or silicone-based softeners used for softening purposes are included in the process [29]. The second most common problem is blue floor defect which accounts for $19,86 \%$ of the total defect. At the end of washing process control, blue, light, or dark color appears on the floor. These products are divided into repair as insufficient or intensive local permanganant and insufficient and intensive pigment locally. The background color becomes blue due to back-staining and during the backstaining process the indigo dyestuff precipitates on the floor. With this collapse, white weft yarns are contaminated. Back staining is solved by ozone and this increases energy costs. Processes to be performed in industrial washing machines and spray sections bring extra energy, chemical, and labor costs [29]. Another problem identified is the light floor which constitutes $10.71 \%$ of the defects. The light color of the products is tried to be caught with enzymes according to different species and temperatures. When the undesirable light floor color emerges in the washing process, any dyestuff used in the product itself can be driven, or the dyestuff in a different color is reduced and soiled by machine exhaustion. Besides, preventive softeners are also used to prevent open floor problems.

In order to avoid undergoing further processes and to prevent stains and irregularities before other processes, it is necessary to resolve the softener in the washing process. Another problem is dark ground and constitutes $7.95 \%$ of the total defect. Since the ground color is dark, denim products that are deemed defective are controlled in color until they reach the desired surface and the parameters such as temperature, time, and concentration are adjusted according to the target sample. In the washing process, sodium hypochlorite or potassium permanganant bleaching process, neutralization and rinsing are performed respectively for products with dark ground defects. Another factor in the dark color of the background is the inadequate abrasion effect. As the defect correcting process, additional abrasion and rinsing are carried out and drying is started [29].

For the purpose of sighting and controlling the variation in the process output, the defect rate control chart is prepared using the data that recorded the defects seen in the washing process. The daily controlled product amounts are different for the period in which Laney $\mathrm{P}$ chart is prepared. To prepare the chart, values that were found by using formula [27] and $Z_{i}$ that was calculated for each day can be seen in Table 3. $Z_{\mathrm{i}}$ reflects deviations from upper control limits (UCL) lower control limits (LCL), and centerline scores of these both UCL and LCL. Formula for $\mathrm{Z}_{\mathrm{i}}$ is[27] :

$\mathrm{Z}_{\mathrm{i}} \cdot \sqrt{\frac{p i-\bar{p}}{\left(\frac{p(1-\bar{p})}{n_{i}}\right)}}$

Depending on the production per unit time, the control charts will have variable sample sizes in the enterprises where the controlled quantity varies. So Laney $\mathrm{P}$ control chart, which is widely used in quality monitoring that has a very large sample size [30], will be useful for this study. Because it is not possible to control the processes spontaneously, the controlling graphics used are very important to eliminate identifiable causes, to reduce variability in the process, and to maintain process performance. For this purpose, the fact that all points in the Laney $\mathrm{P}$ control chart are within the control limits and it indicates that the process is kept under control. If the values exceeding the upper control limits were found, special factors should be studied and necessary corrections should be made. The fact that the majority of the dots are under the midline may mean an improvement in quality. (See Figure 4 and dates: $1.11-6.11 ; 8.11-14.11 ; 25.11)$. Moreover, dots between 14.11 and 22.11 as subgroup numbers are almost with average values and this shows that the process is under control.

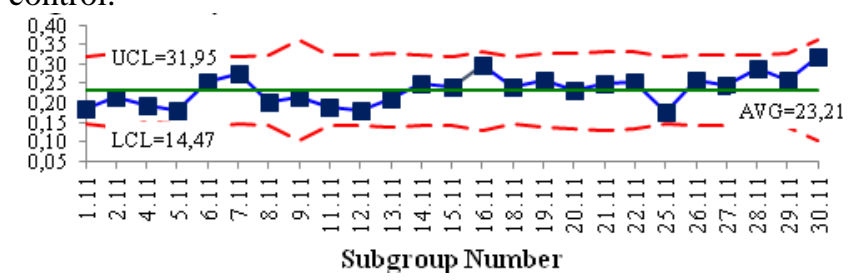

Figure 4. Laney P'Chart

Values below the lower control limit indicate that the defect rate was very low in this period. In these cases, the reasons for these improvements need to be investigated. 
Table 3. Defect Rate $P$ Control Chart Data

\begin{tabular}{cccccccc}
\hline $\begin{array}{c}\text { Sample } \\
\text { Numbers } \\
\text { Date) }\end{array}$ & Cont. Numbers & $\begin{array}{c}\text { Number of } \\
\text { Defects }\end{array}$ & $\begin{array}{c}\text { Defects } \\
\text { Ratio }(\boldsymbol{p})\end{array}$ & $\begin{array}{c}\text { Center } \\
-\end{array}$ & UCL & LCL & $\mathbf{Z}_{\boldsymbol{i}}$ \\
\hline 01.11 .19 & 34791 & 6447 & 0,19 & 0,23 & 0,2389 & 0,2253 & 0,1852 \\
02.11 .19 & 29293 & 6298 & 0,22 & 0,23 & 0,2395 & 0,2247 & 0,2149 \\
04.11 .19 & 39561 & 7720 & 0,20 & 0,23 & 0,2384 & 0,2257 & 0,1951 \\
05.11 .19 & 34696 & 6265 & 0,18 & 0,23 & 0,2389 & 0,2253 & 0,1805 \\
06.11 .19 & 30812 & 7877 & 0,26 & 0,23 & 0,2393 & 0,2249 & 0,2556 \\
07.11 .19 & 35456 & 9776 & 0,28 & 0,23 & 0,2388 & 0,2253 & 0,2757 \\
08.11 .19 & 33032 & 6661 & 0,20 & 0,23 & 0,2390 & 0,2251 & 0,2016 \\
09.11 .19 & 15513 & 3332 & 0,21 & 0,23 & 0,2422 & 0,2219 & 0,2147 \\
11.11 .19 & 33133 & 6306 & 0,19 & 0,23 & 0,2390 & 0,2251 & 0,1903 \\
12.11 .19 & 32915 & 5983 & 0,18 & 0,23 & 0,2391 & 0,2251 & 0,1817 \\
13.11 .19 & 28708 & 6074 & 0,21 & 0,23 & 0,2395 & 0,2246 & 0,2115 \\
14.11 .19 & 31664 & 7936 & 0,25 & 0,23 & 0,2392 & 0,2250 & 0,2506 \\
15.11 .19 & 33360 & 8103 & 0,24 & 0,23 & 0,2390 & 0,2251 & 0,2428 \\
16.11 .19 & 25873 & 7675 & 0,30 & 0,23 & 0,2399 & 0,2242 & 0,2966 \\
18.11 .19 & 36361 & 8844 & 0,24 & 0,23 & 0,2387 & 0,2254 & 0,2432 \\
19.11 .19 & 28729 & 7410 & 0,26 & 0,23 & 0,2395 & 0,2246 & 0,2579 \\
20.11 .19 & 28040 & 6537 & 0,23 & 0,23 & 0,2396 & 0,2245 & 0,2331 \\
21.11 .19 & 25664 & 6385 & 0,25 & 0,23 & 0,2400 & 0,2242 & 0,2487 \\
22.11 .19 & 26355 & 6728 & 0,26 & 0,23 & 0,2399 & 0,2243 & 0,2552 \\
25.11 .19 & 35557 & 6196 & 0,17 & 0,23 & 0,2388 & 0,2254 & 0,1742 \\
26.11 .19 & 32187 & 8385 & 0,26 & 0,23 & 0,2391 & 0,2250 & 0,2604 \\
27.11 .19 & 31100 & 7702 & 0,25 & 0,23 & 0,2393 & 0,2249 & 0,2476 \\
28.11 .19 & 32374 & 9300 & 0,29 & 0,23 & 0,2391 & 0,2250 & 0,2872 \\
29.11 .19 & 28659 & 7386 & 0,26 & 0,23 & 0,2396 & 0,2246 & 0,2577 \\
30.11 .19 & 15426 & 4914 & 0,32 & 0,23 & 0,2423 & 0,2219 & 0,3185 \\
Total & 759259 & 176240 & & & & & \\
\hline & & & & & & & \\
& & & & & & &
\end{tabular}

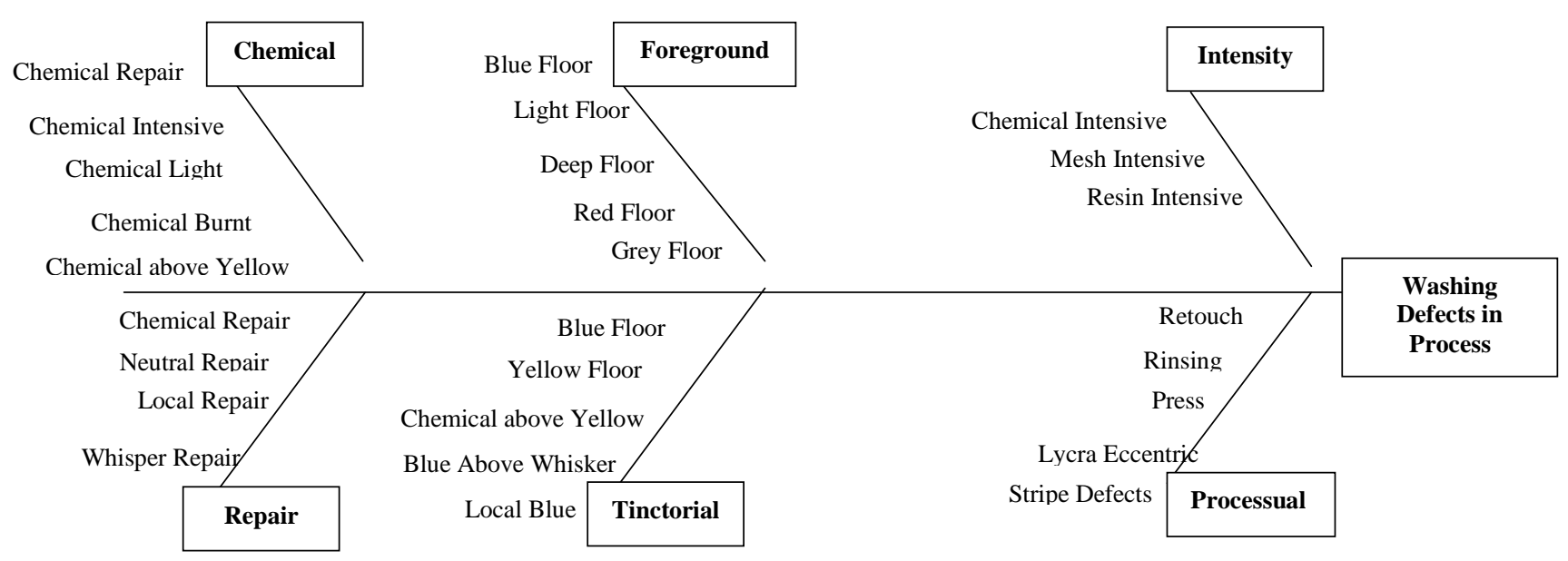

Figure 5. Cause and Effect Diagram

The cause-and-effect diagram for washing defects in the process is illustrated in Figure 5. In the cause-and-effect diagram, washing defects in the process are categorized into chemical, foreground, intensity, repair, tinctorial, and processual. The reason for the washing defects to be collected in the categories is that they are interdependent and interact as a result of being similar to each other. For example, the majority of tinctional flaws emerge with the 
nuanced differences between the colors experienced on the floor and the desired colors after washing in denim fabric. Moreover, chemical defects could be associated with defects in the color category.

\section{CONCLUSION}

After identifying and analyzing cause and effect diagrams washing defects in the process could be reduced by taking corrective actions given in Table 4 .

Washing in the process has been causing some losses and the appropriate identification of washing defects in the process is exact noteworthy for taking helpful actions before other steps in denim production. Washing defects in the process in table 2 are analyzed by Pareto chart. It is revealed that chemical repair constitutes $20.52 \%$, blue floor defect accounts for $19,86 \%$, chemical intensive accounts for $(19,56 \%)$, light floor constitutes $10.71 \%$ and deep floor constitutes $7.95 \%$. Here these 5 major defects comprised of $78,6 \%$ of the total number of defects. Washing process defects are undesirable on the product that has not passed the ending stage.

As a result of the defects in the washing process, products are either sent for repair or the product is removed from the production stage before the final control of the product that is about to be finished and separated as waste. If any washing defect on the finished product is not noticed and the dyeing stage is passed and the finished product reaches the customer in this state, bigger problems arise, and the trust of the customer is shaken. Considering that almost $80 \%$ of the defects encountered and eventually analyzed by Pareto chart and Cause and Effect diagram are chemical and color-based ground defects, it would be the best way to prevent these defects before occurring. In this study, the number of defects detected during and after the washing process of the raw fabrics produced in a denim production facility for 25 days, and quality controls were examined by statistical methods. Data containing 25 days of washing process defects seen as a result of fabric control made by the control staff in the washing section were collected. It is not possible to take measures for all 53 error classes in the defect tracking report and to prevent these defects from occurring. Therefore, the detected defects are listed in order of importance by the Pareto analysis technique. Since the defects in the washing processes cannot be controlled automatically, control cards are used in this study. Laney $P$ control chart was used in this study because the amount of denim that is controlled daily and the defect is different. In this study, the process is under control since all points are within the control limits.

Table 4: Recommended Corrective Actions for Washing Defects in Process.

\begin{tabular}{|c|c|c|c|}
\hline & Defect Type & Causes & Corrective Actions \\
\hline 1 & Chemical Defects & $\begin{array}{l}\text { Desizing enzymes, homogeneity (exceeding } \\
\text { Ph 6-7) }\end{array}$ & $\begin{array}{l}\text { Dispersing Indigos, } \\
\text { Using cationic or silicone for softening }\end{array}$ \\
\hline 2 & Ground Defects & $\begin{array}{l}\text { insufficient or intensive local permanganant } \\
\text { and pigment, }\end{array}$ & Back staining by ozone, \\
\hline 3 & Intensity Problem & $\begin{array}{l}\text { After the type of washing, as a result of the } \\
\text { narrowing in the width and neck of the fabric } \\
\text { and the increase of weft and warp frequencies }\end{array}$ & $\begin{array}{l}\text { Investigations should be made on rins, } \\
\text { enzymes, and stone and stony bleach wash } \\
\text { recipes. Time, temperature and stone used in } \\
\text { washing recipes, enzyme and bleach, weight, } \\
\text { dimensional stability }\end{array}$ \\
\hline 4 & & $\begin{array}{l}\text { Reasons for repairs are wet processes and } \\
\text { operational errors due to spray. }\end{array}$ & $\begin{array}{l}\text { Faulty products with tone difference are ligh } \\
\text { or dark color on the floor, permanganate at } \\
\text { local insufficient or dense }\end{array}$ \\
\hline 5 & Tinctorial & $\begin{array}{l}\text { parameters such as temperature, duration and } \\
\text { concentration }\end{array}$ & $\begin{array}{l}\text { Sodium hypochlorite or potassium } \\
\text { permanganant bleaching process, } \\
\text { neutralization and rinsing }\end{array}$ \\
\hline 6 & Processual & $\begin{array}{l}\text { Failure to rinse with soft water. The problem } \\
\text { that the rinse water is not cold. Failure to } \\
\text { remove peroxide. Hard water causes problems } \\
\text { in dyeing due to the high rate of lime it } \\
\text { contains. }\end{array}$ & $\begin{array}{l}\text { Acetic acid and peroxide killer are added. In } \\
\text { addition to these, soft water is added and } \\
\text { the temperature is raised to } 50 \text { degrees and } \\
\text { kept for } 15 \text { minutes. If peroxide is } 0 \text { and ph } \\
=7 \text {, it means that suitable environment is } \\
\text { provided for dyeing. }\end{array}$ \\
\hline
\end{tabular}


Although the process is seen under control, taking into account the rate of defects encountered and the points of concentration, corrective actions should be taken by taking some precautions to prevent errors encountered in the washing process. Some of these corrective actions are presented with the Cause and Effect diagram, and some number of other suggestions can be submitted to the business. The personnel in the washing department to prevent $80 \%$ of the defects should be gained experience and manual records should be made more systematic and processed on the control cards to ensure that the defects can be observed more clearly and clearly. Detection of defects in the washing process is mostly carried out before proceeding with the rinsing and dyeing process. As seen in Figure 2, according to the alternative flowchart created, when the defect occurs as a result of each process in washing, the next process should not be started, and each process should be gained from the customers' perspective of the previous process. At this point, control charts will be of great help. Thanks to the control charts used to control the continuity of the captured quality level; the reasons for the defects can be investigated and the necessary arrangements can be seen to reach the targeted product quality. Thanks to the decrease in faulty production, operating costs will be significantly reduced in addition to achieving the desired product quality. To clarify the result in one study it is similarly found and addressed that it is essential to control the washing processes and take every stage to minimize industry wastes and environmental pollution by employing different applications such as statistical process control methods with learned restrictions on the products and washing processes. To control it recommends the use of bio-degradable enzymes in place of detrimental chemicals. In case of preventing environmental pollution, fully acquiescence to legal requirements and regulations inducements high priority. In denim washing, usage of chemicals and enzymes, washing conditions, etc. are essential and main factors to reduce costs [31].

The research addressed in the existing paper could be practical to different companies in the textile industry. The result of the research may diverge in concerned companies reliant on the level of preventive/corrective actions thanks to Cause and Effect diagrams and we consider that the research methodology could simply be monitored in other industries for identifying and preventing defects in washing and other processes. In future studies it is advised to be studied control charts and diagrams before controlling the process and after controlling the process.

\section{REFERENCES}

1. Karagöz, G.2009. Denim Yıkama İşlemlerinde Ortaya Çıkan Zararlar Nedenleri ve Çözüm Olanakları, Ege Üniversitesi, Fen Bilimleri Enstitüsü, Tekstil Mühendisliği Ana bilim dalı, Yüksek Lisans Tezi, İzmir.

2. Öcel Y., Arslan H.M. 2018. Hazır Giyim Ürünlerinde Tüketicilerin Demografik Özellikleri İle Renk Algılarının Değerlendirilmesi. Business \& Management Studies: An International Journal 6 (3), 154 170 .

3. İstanbul Tekstil ve Hammaddeleri İhracatçıları Birliği (ITHIB) 2018 Raporu. Erişim: https://www.ithib.org.tr/tr/bilgi-merkezi-raporlaraylik-ihracat-degerlendirme-bilgi-notlari-2018.html

4. Zhao, W.B.2008. Common denim washing technologies (in Chinese) Dyeing Finish. 34 (7), 34-36.

5. Dindar, D., Yavuz, B., 2001. 2000-2001 Moda Trendleri ve Ko Pantolon-Mont Üretimi, Marmara Üniversitesi Teknik Eğitim Fakültesi Tekstil Eğitimi Bölümü, Yüksek Lisans Tezi, İstanbul.

6. Kan, C. W. 2015. Washing techniques for denim jeans. In Denim (pp 313-356). Woodhead Publishing.

7. Pal, S. 2010. Technology of Denim Production: Part-VI (Washing Techniques of Denim). San Blue Enterprises Pvt. Ltd, India.

8. Li, Z.J., Liu, S. 2013. Denim Production Techniques (in Chinese) Donghua University Press Ltd., China

9. Akkurt, İ. (2015). Silikozis. Mesleki Sağlık ve Güvenlik Dergisi (MSG), 9(32).

10. Yi, C.M. 2011. Effect of Washing on Tensile Strength of Denim Fabric, A Thesis Degree of Bachelor of Arts (Honours) Scheme in Institute of Textiles \& Clothing, The Hong Kong Polytechnic University. Hong Kong.

11. Matthews, K. 2018. Encyclopaedic Dictionary of Textile Terms: Volume 3. WPI Publishing.

12. Arjun, Dakurı., Hiranmayee, J., \& Farheen, M. N. 2013. Technology of industrial denim washing. International Journal of Industrial Engineering \& Technology, 3(4), 25-34.

13. Choudhury, A. K. R. 2017. Environmental impacts of denim washing. In Sustainability in Denim (pp. 49-81). Woodhead Publishing.

14. Sweeney, D. 2002. Way To Go Indigo-Using Cellulase To Soften \& Lighten Denim. The American biology teacher, 64(3), 202-208.

15. Jucienè, M., Dobilaitè, V., \& Kazlauskaitè, G. 2006. Influence of industrial washing on denim properties. materials science, 12(4), 355.

16. Mir, S., Hossain, M., Biswas, P., Hossain, A., \& Idris, M. A.2014. Evaluation of mechanical properties of denim garments after enzymatic bio-washing. World Applied Sciences Journal, 31(9), 16611665 .

17. Mezarciöz, S., \& Toksöz, M. 2014. Investıgatıon Of Effect Of Special Washıng Processes On Denım Fabricsr17; Propertıes. Tekstil Ve Konfeksiyon, 24(1), 86-95.

18. Mayang, N., Koeswandi, T. A., \& Yulianti, S. 2016. August). The Analysis of Quality Control in Garment Company Using Statistic in Controling Product. In 2016 Global Conference on Business, Management and Entrepreneurship. Atlantis Press.

19. Paul, R. (Ed.). 2015. Denim: manufacture, finishing and applications. Elsevier.

20. Ahmed, T., Acharjee, R. N., Rahim, M. A., Sikder, N., Akther, T., Khan, M. R., ... \& Saha, A. 2013. An Application of Pareto Analysis and Cause-Effect Diagram for Minimizing Defect Percentage in Sewing Section of a Garment Factory in Bangladesh. International Journal of Modern Engineering Research, Bangladesh.

21. Bhatnagar, R., Joshi, H., Mall, I. D., \& Srivastava, V. C. 2014 Electrochemical treatment of acrylic dye-bearing textile wastewater: optimization of operating parameters. Desalination and Water Treatment, 52(1-3), 111-122. 
22. MacGregor, J. F., \& Kourti, T. 1995. Statistical process control of multivariate processes. Control Engineering Practice, 3(3), 403-414.

23. Patır S. 2009 "İstatistiksel Proses Kontrol Teknikleri ve Kontrol Grafiklerinin Malatya'daki Bir Tekstil (İplik Dokuma) İşletmesinde Bobin Sarım Kontrolüne Uygulanması". Sosyal ve Ekonomik Araştırmalar Dergisi, 12(18), 231-249.

24. Koch, R. 1999. The 80/20 Principle: the secret to achieving more with less, Crown Business, ISBN: 0385491743.

25. Suárez-Barraza, M. F., \& Rodríguez-González, F. G. 2019 Cornerstone root causes through the analysis of the Ishikawa diagram, is it possible to find them?. International Journal of Quality and Service Sciences.

26. Bircan H, Gedik H. 2003. "Tekstil Sektöründe İstatistiksel Proses Kontrol Teknikleri Uygulaması Üzerine Bir Deneme". Çukurova Üniversitesi İktisadi ve İdari Bilimler Dergisi, 4(2), 69-79.
27. Shah, S., Shridhar, P., \& Gohil, D. 2014. Control chart: A statistical process control tool in pharmacy. Asian Journal of Pharmaceutics (AJP): Free full text articles from Asian J Pharm, 4(3).

28. Kunt, A. G. 2004. Denim Kumaşlarda Konfeksiyon Sonrası Yapılan Işslemlerin Kumaş Mekaniği Üzerine Etkisi (Doctoral dissertation, Fen Bilimleri Enstitüsü).

29. Köksal, F. 2015. Denim Ylkamada Renk Varyasyonlarının Nedenlerinin Incelenmesi (Master's Thesis, Namık Kemal Üniversitesi).

30. Ahsan, M., Mashuri, M., \& Khusna, H. 2017. Evaluation of Laney p'Chart Performance. International Journal of Applied Engineering Research, 12(24), 14208-14217.

31. Wickramasinghe, T. 2011. Process improvement in denim washing. 